\title{
Turkish Adaptation of the Early Learning Observation and Rating Scale-Teacher's Form: Validity and Reliability Study and Path Analysis for a Turkey Sample
}

\author{
Ayhan Babaroğlu (iD) and Cem Koçak \\ Faculty of Health Sciences, University of Hitit, 19200 Çorum, Turkey \\ Correspondence should be addressed to Ayhan Babaroğlu; ayhanbabaroglu@hitit.edu.tr
}

Received 19 January 2020; Revised 27 July 2020; Accepted 14 August 2020; Published 1 September 2020

Academic Editor: Haoran Xie

Copyright (c) 2020 Ayhan Babaroğlu and Cem Koçak. This is an open access article distributed under the Creative Commons Attribution License, which permits unrestricted use, distribution, and reproduction in any medium, provided the original work is properly cited.

\begin{abstract}
Acquiring information on the complete development of children during their early childhood, observing their development, and identifying the domains in which they need support have always been very important. There is a parallelism between development in the early period and learning, and development learning is best achieved by learning in children. Children have very different development patterns. As development occurs simultaneously on a broad spectrum of domains, progress in one domain affects the progress in another domain also. Thus, identification of problems in early childhood is important in terms of assessment of child's development and learning. The purpose of th study is adaptation of the early learning observation and rating scale-teacher's form, developed by Coleman, West, and Gillis, to Turkish and the Turkish culture and evaluation of the causality relations between the learning domains through Path analysis in the Turkish sample. Methodologic descriptive and model testing design methods have been used. The study sample consisted of 166 children in the 4-5-year-old group, receiving education in 59 preschool education institutions, and 20 teachers. Simple random sampling method was used in sample selection. Following the Turkish adaptation processes, the validity and reliability of the scale were examined with a pilot study. It was observed that the scale had high appearance-social and scope-construct validity, and the results obtained were coherent with the usefulness and contribution results obtained in the original study. Strong linear relationships were found between each of the seven learning domains in the scale. The early learning observation and rating scale-teacher's form, which was adapted to Turkish, was suitable for use in the Turkish sample and revealed the competence or incompetence condition of children in the learning domains of children correctly and realistically.
\end{abstract}

\section{Introduction}

Development is a product of heredity and the environment in every aspect, and while it may display continuity in certain aspects, it is mainly a phase in terms of other aspects [1-3]. As development is shaped, genetic programs that are capable of determining all successive patterns of subsequent change ensure maturation of the individual. These patterns, which are seen in all children and occur successively independently of cultural structures, are relatively independent of the environmental factors also.

Children, starting their life adventures with birth, display a systematic development, which is established on learning, from most primitive life skills to more complex and advanced level life skills. There is parallelism between development and learning in the early period and development occurs best with learning in children [4-6].

The first learning experiences of life are sensorimotor experiences, which are biological foundations of children regarding their body. Movement, starting with birth and continuing until the end of life, develops from basic movements to rather complex motions [7-9]. Perception starts to develop together with language and concept development. The child also notices physical characteristics such as strength, fastness, endurance, angular motion, balance, direction, and rhythm $[9,10]$. 
Sensorimotor experiences support the social-emotional development of the child to contribute to positive personality development. The child is in close interaction with the parents, teachers, relatives, and peers, who constitute his/her close surrounding. Socializing occurs through learning, and the child may not be aware of this learning at times. Some researchers believe that socializing process actually starts immediately after birth and affects the individual throughout his/her life and that the behavioral patterns are defined during early childhood [11-13].

Development in perception starts with language and concept development. One of the important elements that facilitate both socialization and thinking of the child is language [14]. Language development starts at birth and is a lifelong process. Language and thinking are intertwining concepts in interaction. Learning to use language is a multiphased process. During these phases, memory of the child has a determinant role in the progress of intellectual development $[9,12,13,15]$.

Small children make use of mathematics when making sense of their surrounding and the world and comprehending the physical world. They learn to understand their worlds in terms of numbers and shapes, through mathematics. Development of computational thinking is considered as a very important step although how children's ability towards numbers occurs cannot be explained fully. In the early period, children can count two types of objects by matching them on one to one basis although number conservation skill is not acquired; they can say how many biscuits they want, number of marbles of their friends, and whether these marbles are more or less than their marbles [16-18].

In addition to these general development characteristics, examination of a child's development reveals that it is complex and sophisticated. Children develop physically, emotionally, and socially as they grow and learn. They learn to communicate their needs, requests, and emotions, establish relations with others, and discover the world around them with these relations. It can be said that there is no such thing as "typical" development, and changes observed in the development patterns of small children are normal and expected occurrence [19]. By observing small children, we can see that they develop at different rates and that each child displays strength and difficulty models unique to themselves $[2,3]$. For example, it is seen that there are distinctively different development patterns between Elif, who is capable of telling simple books that were read to her numerous times, without skipping a line and who is leader of the class at age four, and Ali, who does not even know the letters let alone the words, waits until someone approaches him in relations with others, and is even hesitant in terms of participating in group activities. As the learning rates and the growth patterns of small children vary broadly even in a typically accepted expectation group, it is difficult to know early whether there is a problem or not. If some problems are not monitored or observed, the situation may worsen and lead to certain other problems. Some of these problems may have long-term and severe impact on the child's school success and learning in the future. Numerous studies have revealed that early intervention to problem or problems and provision of necessary appropriate support lead to positive impacts on a child's development and success [6, 20-22]. Moreover, identifying children with superior characteristics in terms of development is also important for educational and other planning.

As development occurs on a broad spectrum of domains at the same time, progress in one domain affects the progress in another domain. On the other hand, a problem observed in one domain may have an adverse impact on another development domain. Rating early learning is mainly focused on answering the questions of what the child knows and what is the child capable of doing. Teachers may use different rating tools that they have prepared or standardized tools to make an assessment regarding the development process of each child. The aim is to find the strong and weak aspects of children in terms of development areas and define their probability of needing assistance and identify children who may require special service due to any disability. We know that early support provides backing to the child in the route to success. The first step of early support is identification of the problem.

Early Learning Observation and Rating Scale (ELORS) Teacher's Form is designed to assist teachers in collecting information and documenting the developmental learning levels regarding the child in seven areas of learning. ELORS is based on the systematic observations of children in their natural setting (for instance home, class, playground and neighborhood). Teachers and parents can identify the areas in which the child displays weak or strong development through the use of ELORS. Therefore, children who are in need of assistance and thus who can benefit from additional support may be identified. Identifying the needs of the child is only the first step. Identifying is important because this facilitates responding with appropriate support and moving in the right direction on what must be done subsequently [19].

\section{Materials and Methods}

2.1. Objective of the Study. Early Learning Observation and Rating Scale (ELORS)-Teacher's Form is a scale that was developed by Coleman, West and Gillis in USA in 2010 and is still being used. This scale aims at assisting teachers in treatment of all classes and small groups in early childhood. The main objective of this study is adaptation of the Early Learning Observation and Rating Scale (ELORS)-Teacher's Form to Turkish and to analyze its validity and reliability. Another objective of the study is to apply the ELORS scale that we have adapted to Turkish in a Turkish sample and identify the causality relationships among learning domains. Suitability of the measuring tools to be used in early childhood to the surrounding culture and language is also important in addition to evaluation of the child's development in holistic manner. In this study, the Early Learning Observation and Rating Scale (ELORS)-Teacher's Form is evaluated from this perspective and the issue of whether it can serve Turkish teachers in monitoring learning development of children in their early childhood in Turkey is investigated. 
2.2. Research Design. This research covers adaptation to Turkish of the ELORS scale-teacher's form and methodological, descriptive, and model verification design methods realized for application of the adapted scale.

\subsection{Study Population and Sample. Sample of the study} consists of children in the 4-5-year-old group, attending 59 preschool education institutions, which are affiliated to the Provincial Education Directorate, located at the central district of Çorum Province in the Central Anatolia region of Turkey, in the 2016-2017 education-teaching year. It was determined in the sample selection process that a minimum of 150 children with a significance level of 0.05 needed to be selected in the calculation made with the Simple Random Sample Method. Accordingly, the sample size consisted of 166 children in the 4-5-year-old group. Application was carried out by proportional distribution of the 166 children to seven preschool education institutions selected from among 59 preschool education institutions, affiliated to Çorum Provincial National Education Directorate. Furthermore, data collection phase was realized by 20 teachers in these 7 institutions selected.

2.4. Data Collection Tools. Child Information Form, Teacher Information Form, and Early Learning Observation and Rating Scale (ELORS)-Teacher's Form adapted to Turkish were used in the study.

2.4.1. Child Information Form. This form prepared by the researchers covers information on the age, sex, health condition, number of siblings, education level of parents, and family structure of children included into the study.

2.4.2. Teacher Information Form. This form, which was prepared by the researchers for the teachers who accepted to participate in the study voluntarily, included questions to obtain information on their age, sex, education level, service period, and the age group they work with, and their thoughts on easiness and usefulness of the scale.

2.4.3. Early Learning Observation and Rating Scale (ELORS)-Teacher's Form. Early Learning Observation and Rating Scale (ELORS)-Teacher's Form, developed by Coleman, West, and Gillis (2010) includes the domains of perception-motor, self-management, social-emotional, early math, early literacy, receptive language, and expressive language. The scale is developed to identify the levels of children in the three-five age group in terms of the seven learning domains and to recognize signs pointing to learning difficulties or disabilities early. The scale is applied through observation by the teacher of the child in different activities during the daily routine class programs. In the development process of the original form of the scale, a pool of 245 items was created on seven learning domains. Following various revision works, number of items was first decreased to 143 , and finally, its final version with a total of 70 items with 10 items in each domain was decided upon.

Theoretical and social validity of ELORS was determined with the development process. As a result of literature scanning, examination of other scales, and expert assessment, the theoretical validity of the scale and the domains and items included into the scale were formed. Theoretical validity has verified that these domains and items were more suitable for four-year-olds, that they could be observed in their natural settings, and that they represented early signs of learning difficulties. Social validity of the Early Learning Observation and Rating Scale was determined as a result of review by the board of experts and social validity pilot study. Board of experts determined that use of the domains and items of the scale is socially acceptable for children with cultural and linguistic differences. Moreover, results of the pilot study have shown that the teachers considered use of the scale for various purposes useful [19].

\section{Findings}

3.1. Adaptation to Turkish of the ELORS-Teacher's Form. Firstly, Coleman, West, and Gillis, who developed the scale, were contacted, and necessary consents were obtained for adaptation of ELORS to Turkish. Subsequently, the scale, of which the original language is English, was translated into Turkish by three different English language experts independently and without any changes made on the scale. These translations were translated back to English independently by three different experts, who have a full command of both languages. Following comparison of both translations on one to one basis and examination of meaning equivalence, it was understood that there are no differences between the Turkish and English forms. The scale translated into Turkish was examined by two Turkish language experts and their expertise opinions were obtained. In line with this, it was decided that no further revisions are necessary and the scale was finalized.

Opinions of three experts were consulted in order to determine scope validity and compatibility with the Turkish culture. Experts have examined the terms related with the seven domains of learning in the scale in terms of content, concept, experience, and idiomatics, and it was seen that all items in the scale are compatible in terms of the Turkish culture and language as a result of these reviews. Because holistic evaluation of the child's development and learning, which cover both cognitive and noncognitive domains, is complex, it must take cultural, language, and traditions into account. Suitability of the method and materials only in terms of culture is not adequate. They need to cover the values and skills that are important in a certain culture and national framework also [23].

3.2. Application of ELORS Scale. The scale was applied in 7 schools on 166 children in the 4-5-year-old group by 20 teachers of these students. The teachers were briefed by the researchers on issues such as the objective of the study, method of application, how the forms will be filled, how and 
in which frequency the observations will be made, and interpretation of the outputs before starting of the application. Moreover, the teachers were told that there are certain criteria related with children in the application of the scale, which are as follows:

(i) The child must have attended the class to which he/ she is enrolled for a minimum of one month for inclusion to the study.

(ii) The child must be observed during daily routine activities realized normally in the classroom.

(iii) Observations must be made in periods of 1-2 weeks. Thus, each child will be observed four times during different activities with a period of one week in between within two months.

(iv) Four observations made for each child must be marked on the learning domains provided on the form. The activity during which the observation was made and the period must be written on the form.

(v) Finally, the observation notes must be reviewed and evaluations must be made.

\subsection{Validity and Reliability Studies for the Adaptation to Turkish of the Early Learning Observation and Rating Scale-Teacher's Form}

3.3.1. Face and Social Validity. Applicability and practicality of the Early Learning Observation and Rating Scale-Teacher's Form was evaluated in terms of the teachers to examine Face and Social Validity. 21 volunteer teachers working in 7 different preschool education institutions were selected for this purpose, and each teacher applied the scale on 2 or 3 children in the 4-5-year-old group in their class. As a result of the application by the teachers, information on ease of use the scale by the teachers and practicality of the information obtained from the scale in terms of the teacher is presented in Tables 1 and 2. Examination of Table 1 reveals that 18 out of 21 teachers considered application of the ELORS scale as easy. Similar to the outputs of the original study, this result indicates that this scale is a scale that can be applied easily.

When Table 2 is examined, it is seen that majority of the teachers believe that they can use this scale subsequently also to evaluate the children and that the scale is useful or very useful in planning of learning methods/experiences, establishing communication with parents and understanding the learning needs of the child. It is seen that these outputs are compatible with the results of the original study regarding practicality. Thus, it can be said that ELORS scale is a practical and useful scale in terms of application in Turkey.

Demographic characteristics of the 21 teachers in the pilot study, who considered that the ELORS scale is a scale which is easy to use and useful in general, are presented in Table 3. When the demographic characteristics in Table 3 are compared with the results of the original study, it is seen that the demographic characteristics of the teachers in Turkey are similar to the demographic characteristics of the 16 teachers included in the pilot study during development of the
TABLE 1: Ease of use of the ELORS scale by the teachers.

\begin{tabular}{cccccc}
\hline & Difficult & Slightly difficult & Slightly easy & Easy & Total \\
\hline Teacher & 0 & 1 & 2 & 18 & 21 \\
\hline
\end{tabular}

ELORS scale. Only the mean period of service in the profession of the teachers is approximately 6 years while this was 12 years in the original study. In conclusion, it can be said that the face and social validity of the ELORS scale as a result of the pilot study in Turkey is similar to the face and social validity in the original study. This similarity is important in terms of displaying that the conditions during development of the original scale have been fulfilled in its application in Turkey.

3.3.2. Content Validity. Content validity of the original Early Learning Observation and Rating Scale-Teacher's Form has been ensured. Scale development team carried out comprehensive literature scanning regarding contents. Moreover, other measuring devices serving similar purposes have also been examined. Based on the domain definitions, scale development team evaluated the items in each learning domain, which represent the behaviors that can be observed by the teachers in the classroom, independently and created an items pool consisting of 245 statements. Working on these items, the team selected the items regarding which a consensus was reached. Following reduction of the items, the scale was presented to the review of a board of experts consisting of an independent reviewer. The pilot version consisting of 143 items was developed following arrangements and numerous revisions that were carried out based on the evaluations of the board of experts. It was determined in the pilot application that number of items was excessive and the number of items in each learning domain needed to be reduced to make the use of the scale practical. The item reduction process carried out for this purpose was supported with a verification study. This study was conducted based on the data obtained by 22 teachers who completed these forms with 320 four-year-old children in their class. In conclusion, 10 items which constituted the best indicators for each learning domain were determined and content validity was ensured [19].

In the pilot application of the Turkish adaptation form of the ELORS on 60 children in the 4-5-year-old group, the Cronbach Alpha values, which were recalculated each time an item was deleted so as to ensure content validity of each of the seven learning domains, were examined. According to this, it was seen that 4 items had a slightly reducing effect on reliability. Thus, statements of 1st item in self-management domain, 1st item in receptive language domain, and 1st and 2nd items in expressive language domain were reviewed and changed to make it more comprehensible in terms of Turkish language. Following this revision, it was determined that none of the items of the scale in the research application, consisting of 166 observations, had any adverse effect on reliability in any domain. Thus, it was concluded that content validity of each of the seven learning domains could be established without removing any item from the ELORS. 
TABLE 2: Usefulness of the information obtained by the ELORS scale in terms of the teachers.

\begin{tabular}{lcccc}
\hline Usefulness of information & Useless & Slightly useful & Useful & Very useful \\
\hline Deciding use in the student evaluation in the future & 0 & 0 & 4 & 17 \\
Planning learning methods/experiences & 0 & 2 & 8 & 21 \\
Facilitating communication with parents & 0 & 0 & 7 & 21 \\
Understanding the learning needs of the child & 0 & 0 & 5 & 14 \\
\hline
\end{tabular}

TABLE 3: Demographic characteristics of teachers in the pilot study.

\begin{tabular}{lcc}
\hline \multirow{2}{*}{ Characteristics } & \multicolumn{2}{c}{ Sample size } \\
& $n$ & $\%$ \\
\hline Teacher & 21 & 100 \\
Sex & & \\
Female & 21 & 100 \\
Education level & 2 & \\
Senior high school or equivalent & 13 & 9.5 \\
Associate degree & 6 & 61.9 \\
Bachelor's degree & 6 years & \\
Professional experience & & \\
\hline
\end{tabular}

3.3.3. Construct Validity. Confirmatory Factor Analysis method is used in the examination of the construct validity of the Turkish form of ELORS. Confirmatory Factor Analyses were realized with the Lisreal Program. Firstly, it was investigated whether Turkish form of the ELORS scale was fit for the construct of the original ELORS scale for the pilot application consisting of 60 observations. Based on the resulting path diagram, it was seen that the $t$ values obtained for each item of each learning area, consisting of 10 articles, were substantially higher than the table value of 3.44 for $\alpha=0.001$ (Table 4). This shows that the 10 items each specified in the original scale are items that measure the related learning areas. Thus, it is understood that study data can be reached from the scale without any items being deleted. In addition, it was seen that the Chi square has a high value of 4481.03 and that the compatibility of the model is weak in general compared to other model fit criteria. It is considered that this is due use of small sample group of 60 observations. The Confirmatory Factor Analysis was repeated after application of the Turkish Form of ELORS to a study group of 166 observations. Each $t$-value obtained from the resulting Path diagram of form the main study group being higher values than the $t$ values obtained in the pilot application showed that each item supported each learning area in a stronger manner. Each item explained each respective learning area with value in the range of $34 \%$ and $52 \%$ (Table 4). Moreover, examination of the fit indices obtained as a result of factor analysis has shown that the Turkish form of ELORS has a perfect fit with the construct of the original ELORS scale (Table 5). In conclusion, it can be said that the construct validity of the Turkish form of ELORS is perfect when a sample of sufficient size is selected.

3.3.4. Reliability Analysis. Internal consistency analysis of Turkish form of ELORS was realized individually for each of the seven learning domains. Thus, average interitem correlation and Cronbach Alpha values were obtained for each domain (Table 6). The correlation mean values obtained are acceptable values, and it is understood on the basis of both the pilot application outputs and the research data outputs that each domain is a highly reliable one-dimensioned subscale with high Cronbach Alpha values (Table 6).

\section{Statistical Application of ELORS Turkish Form}

4.1. Descriptive Statistics. Breakdown of the demographic characteristics of the research group consisting of $166 \mathrm{ob}-$ servations is presented in Table 7. Based on this breakdown, it is seen that majority of children included in the study are 4 years old, do not have health problems, have siblings in the $0-2$ range, and have university graduate parents and that the sex distribution of children (boys and girls) is approximately equal.

Descriptive statistics and frequency distributions calculated for each learning domain of ELORS are presented in Table 8 . Based on Table 8 , it can be said that majority of children have scores that are normal or above with the mean of each subdimension being higher than 3 . This finding is compatible with the finding that scores were found to be mostly 3 and 4 during the development of the ELORS original form. From detailed examination of descriptive statistics, the learning domains of children in the 4-5-yearold group in the Çorum sample in Turkey can be listed from best level to weaker level as receptive language, perceptual motor, social and emotional, expressive language, selfmanagement, early math, and early literacy. This order shows that best learning domains of children compared to others are receptive language and perceptual motor while the weakest compared to others are early literacy and early math (Table 8).

For the Turkey sample, it has been found that the expressive language has the best level compared to other learning areas. The arithmetical mean of the receptive language domain of the children is $3.63 \pm 0.63$. The percentage of children with a receptive language domain of normal and above is $95 \%$ and approximately $57 \%$ of this $95 \%$ consists mainly of children with a receptive language domain at excellent level. It is found that early literacy domain is the weakest learning domain compared to other learning domains. The percentage of children with an early literacy domain of normal and above is $74 \%$ and only $0.6 \%$ of this $74 \%$ consist of children with a receptive language domain at excellent level (Table 8).

ELORS scale is a tool that facilitates early identification and understanding of possible signs pointing to learning difficulty levels in the seven learning domains for small children [19]. Although, in line with the objective of the 
TABLE 4: Statistical results of path diagram obtained from confirmatory factor analysis.

\begin{tabular}{|c|c|c|c|c|c|c|c|c|c|}
\hline \multicolumn{6}{|c|}{ Pilot study $(n=60)$} & \multicolumn{4}{|c|}{ Main (application) study } \\
\hline & Equation & $t$-value & Significant & $R$-square & & Equation & $t$-value & Significant & $R$-square \\
\hline $\begin{array}{l}\text { Domain 1: } \\
\text { perceptual } \\
\text { motor }\end{array}$ & $\begin{aligned} \mathrm{AM} 1 & =0.53 * \mathrm{~L} 1 \\
\mathrm{AM} 2 & =0.68 * \mathrm{~L} 1 \\
\mathrm{AM} 3 & =0.59 * \mathrm{~L} 1 \\
\mathrm{AM} 4 & =0.47 * \mathrm{~L} 1 \\
\mathrm{AM} 5 & =0.52 * \mathrm{~L} 1 \\
\mathrm{AM} 6 & =0.65 * \mathrm{~L} 1 \\
\mathrm{AM} & =0.58 * \mathrm{~L} 1 \\
\mathrm{AM} 8 & =0.63 * \mathrm{~L} 1 \\
\mathrm{AM} & =0.69 * \mathrm{~L} 1 \\
\mathrm{AM} 10 & =0.56 * \mathrm{~L} 1\end{aligned}$ & $\begin{array}{l}t=6.86 \\
t=8.56 \\
t=9.10 \\
t=7.60 \\
t=7.96 \\
t=8.37 \\
t=6.75 \\
t=9.57 \\
t=9.56 \\
t=6.69\end{array}$ & $\begin{array}{l}p<0.001^{* * *} \\
p<0.001^{* * *} \\
p<0.001^{* * *} \\
p<0.001^{* * *} \\
p<0.001^{* * *} \\
p<0.001^{* * *} \\
p<0.001^{* * *} \\
p<0.001^{* * *} \\
p<0.001^{* * *} \\
p<0.001^{* * *}\end{array}$ & $\begin{array}{l}R^{2}=0.58 \\
R^{2}=0.77 \\
R^{2}=0.83 \\
R^{2}=0.66 \\
R^{2}=0.71 \\
R^{2}=0.75 \\
R^{2}=0.56 \\
R^{2}=0.88 \\
R^{2}=0.88 \\
R^{2}=0.56\end{array}$ & $\begin{array}{l}\text { Domain 1: } \\
\text { perceptual } \\
\text { motor }\end{array}$ & $\begin{array}{l}\text { AM1 }=0.59 * \mathrm{~L} 1 \\
\text { AM2 }=0.58 * \mathrm{~L} 1 \\
\text { AM3 }=0.76 * \mathrm{~L} 1 \\
\text { AM4 }=0.66 * \mathrm{~L} 1 \\
\text { AM5 }=0.92 * \mathrm{~L} 1 \\
\text { AM6 }=0.60 * \mathrm{~L} 1 \\
\text { AM7 }=0.81 * \mathrm{~L} 1 \\
\text { AM8 }=0.79 * \mathrm{~L} 1 \\
\text { AM9 }=0.83 * \mathrm{~L} 1 \\
\text { AM10 }=0.58 * \mathrm{~L} 1\end{array}$ & $\begin{aligned} t & =9.08 \\
t & =9.34 \\
t & =9.37 \\
t & =9.15 \\
t & =8.91 \\
t & =8.77 \\
t & =8.50 \\
t & =8.82 \\
t & =10.01 \\
t & =7.79\end{aligned}$ & $\begin{array}{l}p<0.001^{* * *} \\
p<0.001^{* * *} \\
p<0.001^{* * *} \\
p<0.001^{* * *} \\
p<0.001^{* * *} \\
p<0.001^{* * *} \\
p<0.001^{* * *} \\
p<0.001^{* * *} \\
p<0.001^{* * *} \\
p<0.001^{* * *}\end{array}$ & $\begin{array}{l}R^{2}=0.43 \\
R^{2}=0.45 \\
R^{2}=0.45 \\
R^{2}=0.43 \\
R^{2}=0.42 \\
R^{2}=0.41 \\
R^{2}=0.39 \\
R^{2}=0.41 \\
R^{2}=0.50 \\
R^{2}=0.34\end{array}$ \\
\hline $\begin{array}{l}\text { Domain 2: } \\
\text { self- } \\
\text { management }\end{array}$ & $\begin{array}{l}\mathrm{OY} 1=0.43 * \mathrm{~L} 2 \\
\mathrm{OY} 2=0.54 * \mathrm{~L} 2 \\
\mathrm{OY} 3=0.50 * \mathrm{~L} 2 \\
\mathrm{OY} 4=0.47 * \mathrm{~L} 2 \\
\mathrm{OY} 5=0.42 * \mathrm{~L} 2 \\
\mathrm{OY} 6=0.62 * \mathrm{~L} 2 \\
\mathrm{OY} 7=0.73 * \mathrm{~L} 2 \\
\mathrm{OY} 8=0.61 * \mathrm{~L} 2 \\
\mathrm{OY} 9=0.47 * \mathrm{~L} 2 \\
\text { OY10 }=0.45 * \mathrm{~L} 2\end{array}$ & $\begin{array}{l}t=4.89 \\
t=7.38 \\
t=7.56 \\
t=5.26 \\
t=3.92 \\
t=7.11 \\
t=7.89 \\
t=8.00 \\
t=5.47 \\
t=5.76\end{array}$ & $\begin{array}{l}p<0.001^{* * *} \\
p<0.001^{* * *} \\
p<0.001^{* * *} \\
p<0.001^{* * *} \\
p<0.001^{* * *} \\
p<0.001^{* * *} \\
p<0.001^{* * *} \\
p<0.001^{* * *} \\
p<0.001^{* * *} \\
p<0.001^{* * *}\end{array}$ & $\begin{array}{l}R^{2}=0.35 \\
R^{2}=0.65 \\
R^{2}=0.67 \\
R^{2}=0.39 \\
R^{2}=0.24 \\
R^{2}=0.62 \\
R^{2}=0.71 \\
R^{2}=0.72 \\
R^{2}=0.42 \\
R^{2}=0.45\end{array}$ & $\begin{array}{l}\text { Domain 2: } \\
\text { self- } \\
\text { management }\end{array}$ & $\begin{array}{l}\mathrm{OY} 1=0.73 * \mathrm{~L} 2 \\
\mathrm{OY} 2=0.77 * \mathrm{~L} 2 \\
\mathrm{OY} 3=0.75 * \mathrm{~L} 2 \\
\mathrm{OY} 4=0.91 * \mathrm{~L} 2 \\
\mathrm{OY} 5=1.37 * \mathrm{~L} 2 \\
\mathrm{OY} 6=0.58 * \mathrm{~L} 2 \\
\text { OY7 }=0.62 * \mathrm{~L} 2 \\
\text { OY } 8=0.79 * \mathrm{~L} 2 \\
\text { OY9 }=1.34 * \mathrm{~L} 2 \\
\text { OY10 }=0.63 * \mathrm{~L} 2\end{array}$ & $\begin{aligned} t & =9.39 \\
t & =9.54 \\
t & =9.18 \\
t & =9.96 \\
t & =9.91 \\
t & =9.14 \\
t & =9.33 \\
t & =9.59 \\
t & =10.12 \\
t & =9.23\end{aligned}$ & $\begin{array}{l}p<0.001^{* * *} \\
p<0.001^{* * *} \\
p<0.001^{* * *} \\
p<0.001^{* * *} \\
p<0.001^{* * *} \\
p<0.001^{* * *} \\
p<0.001^{* * *} \\
p<0.001^{* * *} \\
p<0.001^{* * *} \\
p<0.001^{* * *}\end{array}$ & $\begin{array}{l}R^{2}=0.44 \\
R^{2}=0.45 \\
R^{2}=0.43 \\
R^{2}=0.48 \\
R^{2}=0.48 \\
R^{2}=0.42 \\
R^{2}=0.44 \\
R^{2}=0.45 \\
R^{2}=0.49 \\
R^{2}=0.43\end{array}$ \\
\hline $\begin{array}{l}\text { Domain 3: } \\
\text { social and } \\
\text { emotional }\end{array}$ & $\begin{array}{l}\mathrm{SD} 1=0.41 * \mathrm{~L} 3 \\
\mathrm{SD} 2=0.63 * \mathrm{~L} 3 \\
\mathrm{SD} 3=0.54 * \mathrm{~L} 3 \\
\mathrm{SD} 4=0.59 * \mathrm{~L} 3 \\
\mathrm{SD} 5=0.49 * \mathrm{~L} 3 \\
\mathrm{SD} 6=0.62 * \mathrm{~L} 3 \\
\mathrm{SD} 7=0.53 * \mathrm{~L} 3 \\
\mathrm{SD} 8=0.58 * \mathrm{~L} 3 \\
\mathrm{SD} 9=0.69 * \mathrm{~L} 3 \\
\mathrm{SD} 10=0.26 * \mathrm{~L} 3\end{array}$ & $\begin{array}{l}t=6.07 \\
t=7.92 \\
t=7.83 \\
t=6.84 \\
t=5.48 \\
t=6.44 \\
t=5.57 \\
t=5.68 \\
t=8.33 \\
t=4.11\end{array}$ & $\begin{array}{l}p<0.001^{* * *} \\
p<0.001^{* * *} \\
p<0.001^{* * *} \\
p<0.001^{* * *} \\
p<0.001^{* * *} \\
p<0.001^{* * *} \\
p<0.001^{* * *} \\
p<0.001^{* * *} \\
p<0.001^{* * *} \\
p<0.001^{* * *}\end{array}$ & $\begin{array}{l}R^{2}=0.49 \\
R^{2}=0.71 \\
R^{2}=0.70 \\
R^{2}=0.58 \\
R^{2}=0.42 \\
R^{2}=0.54 \\
R^{2}=0.43 \\
R^{2}=0.45 \\
R^{2}=0.76 \\
R^{2}=0.26\end{array}$ & $\begin{array}{l}\text { Domain 3: } \\
\text { social and } \\
\text { emotional }\end{array}$ & $\begin{aligned} \mathrm{SD} 1 & =1.48 * \mathrm{~L} 3 \\
\mathrm{SD} 2 & =0.66 * \mathrm{~L} 3 \\
\mathrm{SD} 3 & =1.10 * \mathrm{~L} 3 \\
\mathrm{SD} 4 & =0.76 * \mathrm{~L} 3 \\
\mathrm{SD} 5 & =0.69 * \mathrm{~L} 3 \\
\mathrm{SD} 6 & =0.77 * \mathrm{~L} 3 \\
\mathrm{SD} 7 & =0.78 * \mathrm{~L} 3 \\
\mathrm{SD} 8 & =0.68 * \mathrm{~L} 3 \\
\mathrm{SD} 9 & =1.27 * \mathrm{~L} 3 \\
\mathrm{SD} 10 & =1.06 * \mathrm{~L} 3\end{aligned}$ & $\begin{array}{l}t=9.95 \\
t=9.02 \\
t=9.13 \\
t=8.78 \\
t=9.37 \\
t=9.65 \\
t=9.72 \\
t=8.98 \\
t=9.16 \\
t=9.77\end{array}$ & $\begin{array}{l}p<0.001^{* * *} \\
p<0.001^{* * *} \\
p<0.001^{* * *} \\
p<0.001^{* * *} \\
p<0.001^{* * *} \\
p<0.001^{* * *} \\
p<0.001^{* * *} \\
p<0.001^{* * *} \\
p<0.001^{* * *} \\
p<0.001^{* * *}\end{array}$ & $\begin{array}{l}R^{2}=0.49 \\
R^{2}=0.42 \\
R^{2}=0.43 \\
R^{2}=0.40 \\
R^{2}=0.44 \\
R^{2}=0.46 \\
R^{2}=0.47 \\
R^{2}=0.42 \\
R^{2}=0.43 \\
R^{2}=0.47\end{array}$ \\
\hline $\begin{array}{l}\text { 4: } \\
\text { th }\end{array}$ & $\begin{aligned} \mathrm{EM} 1 & =0.67 * \mathrm{~L} 4 \\
\mathrm{EM} 2 & =0.64 * \mathrm{~L} 4 \\
\mathrm{EM} 3 & =0.53 * \mathrm{~L} 4 \\
\mathrm{EM} 4 & =0.78 * \mathrm{~L} 4 \\
\mathrm{EM} 5 & =0.44 * \mathrm{~L} 4 \\
\mathrm{EM} 6 & =0.62 * \mathrm{~L} 4 \\
\mathrm{EM} 7 & =0.60 * \mathrm{~L} 4 \\
\mathrm{EM} 8 & =0.75 * \mathrm{~L} 4 \\
\mathrm{EM} 9 & =0.68 * \mathrm{~L} 4 \\
\mathrm{EM} 10 & =0.66 * \mathrm{~L} 4\end{aligned}$ & $\begin{array}{l}t=8.11 \\
t=8.84 \\
t=8.16 \\
t=9.60 \\
t=7.41 \\
t=8.68 \\
t=8.25 \\
t=9.40 \\
t=7.23 \\
t=8.69\end{array}$ & $\begin{array}{l}p<0.001^{* * *} \\
p<0.001^{* * *} \\
p<0.001^{* * *} \\
p<0.001^{* * *} \\
p<0.001^{* * *} \\
p<0.001^{* * *} \\
p<0.001^{* * *} \\
p<0.001^{* * *} \\
p<0.001^{* * *} \\
p<0.001^{* * *}\end{array}$ & $\begin{array}{l}R^{2}=0.72 \\
R^{2}=0.80 \\
R^{2}=0.73 \\
R^{2}=0.88 \\
R^{2}=0.64 \\
R^{2}=0.78 \\
R^{2}=0.74 \\
R^{2}=0.86 \\
R^{2}=0.62 \\
R^{2}=0.79\end{array}$ & $\begin{array}{l}\text { Dom } \\
\text { early }\end{array}$ & $\begin{aligned} \mathrm{EM} 1 & =1.25 * \mathrm{~L} 4 \\
\mathrm{EM} 2 & =1.26 * \mathrm{~L} 4 \\
\mathrm{EM} 3 & =1.13 * \mathrm{~L} 4 \\
\mathrm{EM} 4 & =1.33 * \mathrm{~L} 4 \\
\mathrm{EM} 5 & =2.11 * \mathrm{~L} 4 \\
\mathrm{EM} 6 & =0.83 * \mathrm{~L} 4 \\
\mathrm{EM} 7 & =0.76 * \mathrm{~L} 4 \\
\mathrm{EM} 8 & =0.96 * \mathrm{~L} 4 \\
\mathrm{EM} 9 & =0.70 * \mathrm{~L} 4 \\
\mathrm{EM} 10 & =0.93 * \mathrm{~L} 4\end{aligned}$ & $\begin{aligned} t & =10.16 \\
t & =10.22 \\
t & =10.43 \\
t & =10.21 \\
t & =10.10 \\
t & =9.78 \\
t & =9.92 \\
t & =9.22 \\
t & =9.31 \\
t & =9.16\end{aligned}$ & $\begin{array}{l}p<0.001^{* * *} \\
p<0.001^{* * *} \\
p<0.001^{* * *} \\
p<0.001^{* * *} \\
p<0.001^{* * *} \\
p<0.001^{* * *} \\
p<0.001^{* * *} \\
p<0.001^{* * *} \\
p<0.001^{* * *} \\
p<0.001^{* * *}\end{array}$ & $\begin{array}{l}R^{2}=0.50 \\
R^{2}=0.50 \\
R^{2}=0.52 \\
R^{2}=0.50 \\
R^{2}=0.49 \\
R^{2}=0.47 \\
R^{2}=0.48 \\
R^{2}=0.43 \\
R^{2}=0.44 \\
R^{2}=0.43\end{array}$ \\
\hline $\begin{array}{l}\text { n: } \\
\text { teracy }\end{array}$ & $\begin{aligned} \mathrm{EO} 1 & =0.48 * \mathrm{~L} 5 \\
\mathrm{EO} 2 & =0.79 * \mathrm{~L} 5 \\
\mathrm{EO} 3 & =0.54 * \mathrm{~L} 5 \\
\mathrm{EO} 4 & =0.88 * \mathrm{~L} 5 \\
\mathrm{EO} 5 & =0.94 * \mathrm{~L} 5 \\
\mathrm{EO} 6 & =0.88 * \mathrm{~L} 5 \\
\mathrm{EO} 7 & =0.76 * \mathrm{~L} 5 \\
\mathrm{EO} 8 & =0.65 * \mathrm{~L} 5 \\
\mathrm{EO} 9 & =0.65 * \mathrm{~L} 5 \\
\mathrm{EO} 10 & =0.68 * \mathrm{~L} 5\end{aligned}$ & $\begin{array}{l}t=5.28 \\
t=7.79 \\
t=5.67 \\
t=9.07 \\
t=9.23 \\
t=8.48 \\
t=6.60 \\
t=6.52 \\
t=5.38 \\
t=5.64\end{array}$ & $\begin{array}{l}p<0.001^{* * *} \\
p<0.001^{* * *} \\
p<0.001^{* * *} \\
p<0.001^{* * *} \\
p<0.001^{* * *} \\
p<0.001^{* * *} \\
p<0.001^{* * *} \\
p<0.001^{* * *} \\
p<0.001^{* * *} \\
p<0.001^{* * *}\end{array}$ & $\begin{array}{l}R^{2}=0.39 \\
R^{2}=0.69 \\
R^{2}=0.44 \\
R^{2}=0.83 \\
R^{2}=0.85 \\
R^{2}=0.77 \\
R^{2}=0.55 \\
R^{2}=0.54 \\
R^{2}=0.41 \\
R^{2}=0.44\end{array}$ & $\begin{array}{l}\text { Don } \\
\text { early }\end{array}$ & $\begin{aligned} \mathrm{EO} 1 & =1.21 * \mathrm{~L} 5 \\
\mathrm{EO} 2 & =1.53 * \mathrm{~L} 5 \\
\mathrm{EO} 3 & =1.00 * \mathrm{~L} 5 \\
\mathrm{EO} 4 & =0.87 * \mathrm{~L} 5 \\
\mathrm{EO} 5 & =0.80 * \mathrm{~L} 5 \\
\mathrm{EO} 6 & =0.70 * \mathrm{~L} 5 \\
\mathrm{EO} 7 & =0.75 * \mathrm{~L} 5 \\
\mathrm{EO} 8 & =0.75 * \mathrm{~L} 5 \\
\mathrm{EO} 9 & =0.71 * \mathrm{~L} 5 \\
\mathrm{EO} 10 & =0.74 * \mathrm{~L} 5\end{aligned}$ & $\begin{aligned} t & =10.23 \\
t & =10.03 \\
t & =10.06 \\
t & =10.04 \\
t & =10.26 \\
t & =10.08 \\
t & =9.80 \\
t & =9.75 \\
t & =9.92 \\
t & =9.95\end{aligned}$ & $\begin{array}{l}p<0.001^{* * *} \\
p<0.001^{* * *} \\
p<0.001^{* * *} \\
p<0.001^{* * *} \\
p<0.001^{* * *} \\
p<0.001^{* * *} \\
p<0.001^{* * *} \\
p<0.001^{* * *} \\
p<0.001^{* * *} \\
p<0.001^{* * *}\end{array}$ & $\begin{array}{l}R^{2}=0.50 \\
R^{2}=0.49 \\
R^{2}=0.49 \\
R^{2}=0.49 \\
R^{2}=0.50 \\
R^{2}=0.49 \\
R^{2}=0.47 \\
R^{2}=0.47 \\
R^{2}=0.48 \\
R^{2}=0.48\end{array}$ \\
\hline $\begin{array}{l}\text { Domain 6: } \\
\text { receptive } \\
\text { language }\end{array}$ & $\begin{array}{l}\mathrm{AD} 1=0.35 * \mathrm{~L} 6 \\
\mathrm{AD} 2=0.26 * \mathrm{~L} 6 \\
\mathrm{AD} 3=0.36 * \mathrm{~L} 6 \\
\mathrm{AD} 4=0.21 * \mathrm{~L} 6 \\
\mathrm{AD} 5=0.30 * \mathrm{~L} 6 \\
\mathrm{AD} 6=0.33 * \mathrm{~L} 6 \\
\mathrm{AD} 7=0.26 * \mathrm{~L} 6 \\
\mathrm{AD} 8=0.24 * \mathrm{~L} 6 \\
\mathrm{AD} 9=0.41 * \mathrm{~L} 6 \\
\mathrm{AD} 10=0.51 * \mathrm{~L} 6\end{array}$ & $\begin{array}{l}t=4.15 \\
t=5.51 \\
t=6.12 \\
t=5.47 \\
t=6.08 \\
t=6.68 \\
t=4.55 \\
t=5.65 \\
t=6.63 \\
t=6.30\end{array}$ & $\begin{array}{l}p<0.001^{* * *} \\
p<0.001^{* * *} \\
p<0.001^{* * *} \\
p<0.001^{* * *} \\
p<0.001^{* * *} \\
p<0.001^{* * *} \\
p<0.001^{* * *} \\
p<0.001^{* * *} \\
p<0.001^{* * *} \\
p<0.001^{* * *}\end{array}$ & $\begin{array}{l}R^{2}=0.27 \\
R^{2}=0.43 \\
R^{2}=0.51 \\
R^{2}=0.43 \\
R^{2}=0.50 \\
R^{2}=0.57 \\
R^{2}=0.32 \\
R^{2}=0.45 \\
R^{2}=0.57 \\
R^{2}=0.53\end{array}$ & $\begin{array}{l}\text { Domain 6: } \\
\text { receptive } \\
\text { language }\end{array}$ & $\begin{array}{l}\mathrm{AD} 1=1.29 * \mathrm{~L} 6 \\
\mathrm{AD} 2=1.39 * \mathrm{~L} 6 \\
\mathrm{AD} 3=0.98 * \mathrm{~L} 6 \\
\mathrm{AD} 4=1.20 * \mathrm{~L} 6 \\
\mathrm{AD} 5=1.29 * \mathrm{~L} 6 \\
\mathrm{AD} 6=1.11 * \mathrm{~L} 6 \\
\mathrm{AD} 7=1.11 * \mathrm{~L} 6 \\
\mathrm{AD} 8=1.30 * \mathrm{~L} 6 \\
\mathrm{AD} 9=1.42 * \mathrm{~L} 6 \\
\mathrm{AD} 10=1.16 * \mathrm{~L} 6\end{array}$ & $\begin{aligned} t & =10.27 \\
t & =10.47 \\
t & =10.57 \\
t & =10.21 \\
t & =10.25 \\
t & =10.12 \\
t & =10.09 \\
t & =9.97 \\
t & =9.78 \\
t & =9.63\end{aligned}$ & $\begin{array}{l}p<0.001^{* * *} \\
p<0.001^{* * *} \\
p<0.001^{* * *} \\
p<0.001^{* * *} \\
p<0.001^{* * *} \\
p<0.001^{* * *} \\
p<0.001^{* * *} \\
p<0.001^{* * *} \\
p<0.001^{* * *} \\
p<0.001^{* * *}\end{array}$ & $\begin{array}{l}R^{2}=0.50 \\
R^{2}=0.51 \\
R^{2}=0.52 \\
R^{2}=0.49 \\
R^{2}=0.50 \\
R^{2}=0.49 \\
R^{2}=0.49 \\
R^{2}=0.48 \\
R^{2}=0.46 \\
R^{2}=0.45\end{array}$ \\
\hline
\end{tabular}


TABLE 4: Continued.

\begin{tabular}{|c|c|c|c|c|c|c|c|c|c|}
\hline & & ot study & $(n=60)$ & & & $\mathrm{Ma}$ & (applicat & ion) study & \\
\hline & Equation & $t$-value & Significant & $R$-square & & Equation & $t$-value & Significant & $R$-square \\
\hline & $7 * \mathrm{~L} 7$ & $t=3.69$ & $p<0.001^{* * *}$ & $R^{2}=$ & & $1.13 * \mathrm{~L} 7$ & $t=10.21$ & $1^{* * *}$ & $R^{2}=0.50$ \\
\hline & ID2 $=$ & $t=3.59$ & $p<0.001^{* * *}$ & $R^{2}=0.20$ & & $\mathrm{ID} 2=1.38 * \mathrm{~L} 7$ & $t=10.11$ & $p<0.001^{* * *}$ & $R^{2}=0.49$ \\
\hline & $\mathrm{ID} 3=0.63 * \mathrm{~L} 7$ & $t=8.04$ & $p<0.001^{* * *}$ & $R^{2}=0.72$ & & $\mathrm{ID} 3=1.27 * \mathrm{~L} 7$ & $t=10.28$ & $p<0.001^{* * *}$ & $R^{2}=0.50$ \\
\hline & $\mathrm{ID} 4=0.46 * \mathrm{~L} 7$ & $t=7.30$ & $p<0.001^{* * *}$ & $R^{2}=0.63$ & & $1 * \mathrm{~L} 7$ & $t=$ & $p<0.001^{* * *}$ & $R^{2}=0.49$ \\
\hline Domain & ID5 $=0.52 *$ L7 & $t=8.04$ & $p<0.001^{* * *}$ & $R^{2}=0.72$ & & $\mathrm{ID} 5=1.32 * \mathrm{~L} 7$ & $t=10.07$ & $p<0.001^{* * *}$ & $R^{2}=0.48$ \\
\hline 7: expressive & $\mathrm{ID} 6=0.42 * \mathrm{~L} 7$ & $t=7.19$ & $p<0.001^{* * *}$ & $R^{2}=0.62$ & 7: expressi & $\mathrm{ID6}=1.71 * \mathrm{~L} 7$ & $t=9.93$ & $p<0.001^{* * *}$ & $R^{2}=0.49$ \\
\hline & $\mathrm{ID} 7=0.74 * \mathrm{~L} 7$ & $t=8.29$ & $p<0.001^{* * *}$ & $R^{2}=0.75$ & & $\mathrm{ID} 7=1.24 * \mathrm{~L} 7$ & $t=9.79$ & $p<0.001^{* * *}$ & $R^{2}=0.47$ \\
\hline & ID8 $=0.65 *$ L7 & $t=7.85$ & $p<0.001^{* * *}$ & $R^{2}=0.70$ & & $\mathrm{ID} 8=1.27 * \mathrm{~L} 7$ & $t=9.75$ & $p<0.001^{* * *}$ & $R^{2}=0.48$ \\
\hline & ID9 $=0.55 *$ L7 & $t=7.87$ & $p<0.001^{* * *}$ & $R^{2}=0.70$ & & ID9 $=1.48 *$ L7 & $t=9.58$ & $p<0.001^{* * *}$ & $R^{2}=0.45$ \\
\hline & $\mathrm{ID} 10=0.65 * \mathrm{~L} 7$ & $t=7.84$ & $p<0.001^{* * *}$ & $R^{2}=0.70$ & & $\mathrm{ID} 10=2.18 * \mathrm{~L} 7$ & $t=9.31$ & $p<0.001^{* * *}$ & $R^{2}=0.43$ \\
\hline
\end{tabular}

TABLE 5: Evaluation of the fit of the model according to the goodness of fit criteria.

\begin{tabular}{|c|c|c|}
\hline The fit index & Main (application) study & Evaluation \\
\hline Normal theory weighted least squares chi-square $\left(x^{2}\right)$ & $345.73(p=1.00)$ & Acceptable fit \\
\hline$x^{2} / \mathrm{df}$ & 0.15 & Perfect fit $\left(0 \leq x^{2} / \mathrm{df} \leq 2\right)$ \\
\hline Root mean square error of approximation (RMSEA) & 0.00 & Perfect fit $(0 \leq$ RMSEA $\leq 2)$ \\
\hline Goodness of fit index (GFI) & 0.94 & Acceptable fit $(0.90 \leq \mathrm{GFI} \leq 0.95)$ \\
\hline Comparative fit index (CFI) & 1.00 & Perfect fit $(0.95 \leq \mathrm{CFI} \leq 1.00)$ \\
\hline Normed fit index (NFI) & 0.99 & Perfect fit $(0.95 \leq \mathrm{NFI} \leq 1.00)$ \\
\hline Relative fit index (RFI) & 0.99 & Perfect fit $(0.95 \leq \mathrm{RFI} \leq 1.00)$ \\
\hline Standardized root mean square residual (SRMR) & 0.027 & Perfect fit $(0.00 \leq$ SRMR $\leq 0.05)$ \\
\hline
\end{tabular}

TABLE 6: Some statistical results of reliability analysis.

\begin{tabular}{|c|c|c|c|c|c|c|c|c|}
\hline \multirow[b]{2}{*}{$\begin{array}{l}\text { Learning } \\
\text { domains }\end{array}$} & \multicolumn{4}{|c|}{ Pilot study $(n=60)$} & \multicolumn{4}{|c|}{ Main (application) study $(n=166)$} \\
\hline & $\mathrm{KMO}$ & $\begin{array}{c}\text { Average } \\
\text { interitem } \\
\text { correlation }\end{array}$ & $\begin{array}{c}\text { Variance } \\
\text { explanation } \\
\text { percentage }\end{array}$ & $\begin{array}{l}\text { Cronbach } \\
\text { alpha } \\
\text { reliability }\end{array}$ & $\mathrm{KMO}$ & $\begin{array}{l}\text { Correlation } \\
\text { mean among } \\
\text { items }\end{array}$ & $\begin{array}{c}\text { Variance } \\
\text { explanation } \\
\text { percentage }\end{array}$ & $\begin{array}{l}\text { Cronbach } \\
\text { alpha } \\
\text { reliability }\end{array}$ \\
\hline $\begin{array}{l}\text { Perceptual } \\
\text { motor }\end{array}$ & 0.907 & 0.716 & 74.73 & 0.961 & 0.918 & 0.689 & 72.14 & 0.954 \\
\hline $\begin{array}{l}\text { Self- } \\
\text { management }\end{array}$ & 0.824 & 0.510 & 56.78 & 0.910 & 0.944 & 0.735 & 76.16 & 0.964 \\
\hline $\begin{array}{l}\text { Social and } \\
\text { emotional }\end{array}$ & 0.855 & 0.529 & 58.01 & 0.917 & 0.923 & 0.756 & 78.14 & 0.968 \\
\hline Early math & 0.914 & 0.754 & 77.97 & 0.967 & 0.923 & 0.816 & 83.58 & 0.976 \\
\hline Early literacy & 0.851 & 0.587 & 63.32 & 0.934 & 0.948 & 0.827 & 84.41 & 0.978 \\
\hline $\begin{array}{l}\text { Receptive } \\
\text { language }\end{array}$ & 0.781 & 0.453 & 51.29 & 0.875 & 0.937 & 0.868 & 88.15 & 0.981 \\
\hline $\begin{array}{l}\text { Expressive } \\
\text { language }\end{array}$ & 0.872 & 0.573 & 62.99 & 0.932 & 0.946 & 0.835 & 85.17 & 0.979 \\
\hline
\end{tabular}

ELORS scale regarding identification of these learning difficulties, the scores obtained in each of the seven learning domains are high values, children with very weak levels have been examined for each learning domain, and 15 children with minimum one learning domain that is weak have been found out of 166 children. Thus, it can be said that the percentage of children with minimum one very weak level of learning domain is $9 \%$ for the Turkey sample.

4.2. Effect of Demographic Characteristics on ELORS. As a result of the normality analysis of the ELORS scale Turkish Form carried out on 166 children, it was seen that normality assumptions were largely not fulfilled. Thus, it was decided to use the Mann-Whitnes $U$ test in the comparison of two groups and the Kruskal Wallis tests in the comparison of more than two groups. Moreover, as the sample size of 166 is an adequate number, comparisons were made with observation of the median and mean values of the groups together (Table 9). Based on the results obtained, it was determined that the sex of the child, mother's education level and father's education level variables did not have a statistically significant level of effect on any learning domain of ELORS ( $p$ values $>0.05)$. However, the child's age variable affects all sub-learning domains of ELORS at 0.01 and 0.05 significance levels, which is generally at a rate of 0.01.5-year-old children generally have higher level of perceptual motor, self-management, social and emotional, early math, early literacy, 
TABLE 7: Breakdown of demographic characteristics.

\begin{tabular}{lcc}
\hline & Frequency & Percent \\
\hline Age & 101 & \\
4-year-olds & 65 & 60.8 \\
5-year-olds & & 39.2 \\
Health problem & 147 & \\
None & 19 & 11.4 \\
Yes & & \\
Number of siblings & 54 & 32.5 \\
No siblings & 71 & 42.8 \\
1 & 35 & 21.1 \\
2 & 3 & 1.8 \\
3 & 3 & 1.8 \\
4 & & \\
Sex & 73 & 44.0 \\
Girl & 93 & 56.0 \\
Boy & & \\
Mother's education level & 38 & 22.9 \\
Primary education & 56 & 33.7 \\
Senior high school or equivalent & 72 & 43.4 \\
University & & \\
Father's education level & 23 & 13.9 \\
Primary education & 61 & 36.7 \\
Senior high school or equivalent & 82 & 49.4 \\
University & &
\end{tabular}

receptive language and expressive language learning points compared to 4-year-old children.

Development domains, which progress as a whole, are in interaction with one another. At the same time, development shows continuity and occurs in certain stages. For example, children in 2-year-old group start to comprehend images of general objects and words cognitively [24]. However, the difference in terms of learning skills between a 2-year-old at the beginning of the preoperational stage and a 7-year-old at the end of the same period is striking. A 5-year-old child having higher learning points compared to that of a 4-yearold child in the domains of perceptual and motor, selfmanagement, social and emotional, early math, early literacy, receptive language, and expressive language can be construed as a developmental finding, because children in different age groups have different skills of understanding the world and learning. This difference is due to their cognitive development levels being different. Review of the literature on the subject shows that conclusions that support this finding have been reported [25-29].

The child's health condition variable is another variable that can create significant differences on self-management, social-emotional, and receptive language domains of ELORS (Table 9). Thus, it can be said that self-management, socialemotional, and receptive language learning domains of children without any health problems will be at a better level than children with any health problems. Health problems create adverse impacts on academic skills and social relations. It may lead to child facing certain physical difficulties and restrictions, thus preventing daily life activities. It results in communicational problems in children along with associated language skill problems, fall in academic success, and insufficiencies in skills in the social adaptation, cognition, perception, and self-directed learning areas, which are shaped with social adaptation. It is seen that the study findings are coherent with the conclusions in literature [30-34].

It was found that number of siblings of the child affected the social-emotional and expressive language learning domains of ELORS at 0.01 significance levels (Table 9). Based on the findings, it is observed that children with only 1 sibling have better social-emotional and expressive language learning levels compared to those with no siblings or 2 siblings. Sibling relations are a combination of affection and competition. The natural learning environment resulting from being together with siblings of different ages supports children in terms of social-emotional and intellectual developments. Social relationships established by children affect their language development competences. When considered in terms of practical function of language, the child will notice how they see themselves and each other and how they perceive the world around them when they communicate with their sibling(s) through speech [35-37]. The reached conclusion shows that there is an effect of the background characteristics of the family, shared (family size, education level of parents, socioeconomic structures) and non-shared (parent-child relations, order of birth etc.) environmental factors rather than the number of siblings. Examination of the literature shows that there is no consensus in studies that deal with number of siblings and learning relationship in different contexts. However, there are some study findings that support the conclusion we reached in this study [38-40].

\subsection{Relationships between the Learning Domains of ELORS.} Pearson Correlation matrix was obtained for the seven learning domains to examine the linear relationship between the seven learning domains of ELORS, and this matrix is presented in Table 10. Examination of Table 10 shows that each of the seven learning domains of ELORS has a strong relationship with one another at 0.01 ( $p$ values $<\alpha=0.01$ ) significance level.

The fact that there are strong linear relationships between each of the seven learning domains suggests that the score of one domain may be determined jointly by the other domains. For this reason, path analyses were realized to determine the causality between the seven learning domains of ELORS. During path analysis, each of the seven learning domains have been taken as dependent variables in sequence with the others being considered independent variables, so that seven path analyses were carried out. First the multiple regression equation was obtained for the six independent variables during any path analysis. Afterwards, independent variables that do not affect the dependent variable at a statistically significant level were removed from the equation to obtain a multiple regression with less than six independent variables. With the use of these multiple models obtained, the direct and indirect effects of the independent variables on the dependent variable were calculated numerically. As a result of the analysis, the effect levels were calculated so that total of the indirect and direct effects is 
Table 8: Descriptive statistics and frequency distributions $(n=166)$.

\begin{tabular}{|c|c|c|c|c|c|}
\hline Learning domain & Median & Mean \pm SD & Score & Frequency & Percent \\
\hline \multirow{5}{*}{ Perceptual motor } & \multirow{5}{*}{3.70} & \multirow{5}{*}{$3.53 \pm 0,53$} & $1-1.75$ (very weak) & 0 & 0 \\
\hline & & & $1.75-2.5$ (weak) & 9 & 5.4 \\
\hline & & & $2.5-3.25$ (normal) & 31 & 18.7 \\
\hline & & & $3.25-4$ (very good) & 75 & 45.2 \\
\hline & & & 4 (excellent) & 51 & 30.7 \\
\hline \multirow{5}{*}{ Self-management } & \multirow{5}{*}{3.60} & \multirow{5}{*}{$3.35 \pm 0.59$} & $1-1.75$ (very weak) & 2 & 1.2 \\
\hline & & & $1.75-2.5$ (weak) & 15 & 9.0 \\
\hline & & & $2.5-3.25$ (normal) & 42 & 25.3 \\
\hline & & & $3.25-4$ (very good) & 92 & 55.4 \\
\hline & & & 4 (excellent) & 15 & 9.0 \\
\hline \multirow{5}{*}{ Social and emotional } & \multirow{5}{*}{3.70} & \multirow{5}{*}{$3.41 \pm 0.64$} & $1-1.75$ (very weak) & 1 & .6 \\
\hline & & & $1.75-2.5$ (weak) & 22 & 13.3 \\
\hline & & & $2.5-3.25$ (normal) & 28 & 16.9 \\
\hline & & & $3.25-4$ (very good) & 86 & 51.8 \\
\hline & & & 4 (excellent) & 29 & 17.5 \\
\hline \multirow{5}{*}{ Early math } & \multirow{5}{*}{3.50} & \multirow{5}{*}{$3.26 \pm 0.67$} & $1-1.75$ (very weak) & 6 & 3.6 \\
\hline & & & $1.75-2.5$ (weak) & 11 & 6.6 \\
\hline & & & $2.5-3.25$ (normal) & 52 & 31.3 \\
\hline & & & $3.25-4$ (very good) & 81 & 48.8 \\
\hline & & & 4 (excellent) & 16 & 9.6 \\
\hline \multirow{5}{*}{ Early literacy } & \multirow{5}{*}{3.25} & \multirow{5}{*}{$3.01 \pm 0.70$} & $1-1.75$ (very weak) & 7 & 4.2 \\
\hline & & & $1.75-2.5$ (weak) & 36 & 21.7 \\
\hline & & & $2.5-3.25$ (normal) & 40 & 24.1 \\
\hline & & & $3.25-4$ (very good) & 82 & 49.4 \\
\hline & & & 4 (excellent) & 1 & .6 \\
\hline \multirow{5}{*}{ Receptive language } & \multirow{5}{*}{4.00} & \multirow{5}{*}{$3.63 \pm 0.63$} & $1-1.75$ (very weak) & 4 & 2.4 \\
\hline & & & $1.75-2.5$ (weak) & 13 & 7.8 \\
\hline & & & $2.5-3.25$ (normal) & 14 & 8.4 \\
\hline & & & $3.25-4$ (very good) & 41 & 24.7 \\
\hline & & & 4 (excellent) & 94 & 56.6 \\
\hline \multirow{5}{*}{ Expressive language } & \multirow{5}{*}{3.70} & \multirow{5}{*}{$3.35 \pm 0.76$} & $1-1.75$ (very weak) & 12 & 7.2 \\
\hline & & & $1.75-2.5$ (weak) & 14 & 8.4 \\
\hline & & & $2.5-3.25$ (normal) & 22 & 13.3 \\
\hline & & & $3.25-4$ (very good) & 111 & 66.9 \\
\hline & & & 4 (excellent) & 7 & 4.2 \\
\hline
\end{tabular}

equal to the total effect [41]. Statistical results obtained from path analysis are presented in Table 11.

Examination of Table 11 shows that the only variable that affects the perceptual motor learning domain at a statistically significant level is the self-management learning domain with an explanation rate of $57 \%$. This $57 \%$ effect is a direct effect, and the remaining $43 \%$ effect results from variables that are not discussed in this study. Thus, this means that when the self-management domain of the child is developed with priority, the perceptual motor domain will develop at a certain level. Similarly, it is seen that the only variable that affects the early mathematics learning domain at a statistically significant level is the early literacy learning domain with an explanation rate of approximately $70 \%$. This $70 \%$ effect is a direct effect and means that if the early literacy of the child is developed with priority, early math domain will also be developed directly.

It is seen in Table 11 that the variables that affect both the social-emotional and the receptive language learning domains at a statistically significant manner are the self-management and expressive language domains. Social and emotional area is affected from firstly the self-management area with an effect rate of $49.5 \%$ and secondly from the receptive language domain with an effect rate of $22.6 \%$. When these effects are examined, it is seen that the direct effect of self-management domain and the indirect effect of the receptive language domain are higher. For this reason, one may say that development of self-management and expressive language domains with priority given to the self-management domain will be useful for a child who is considered as having a problem in the social and emotional learning domain. However, it would be wise to develop the selfmanagement and expressive language domains with priority given to expressive language for a child who is considered as having a problem in the receptive language domain. Because expressive language domain affects the receptive language area with an explanation rate of $74.5 \% .65 .1 \%$ of this rate is a direct effect. In addition, effect of self-management domain on receptive language domain is a $12.1 \%$ effect, of which $10 \%$ is indirect.

According to Table 11, there are 3 variables that affect the early literacy learning domain at a statistically significant level with an explanation rate of $78.7 \%$. These variables are listed in order of importance as early math with an effect rate of $38.5 \%$, self-management with an effect rate of $20.9 \%$, and 
TABLE 9: Demographic characteristics affecting the ELORS score at significant levels.

\begin{tabular}{|c|c|c|c|c|c|}
\hline Learning domain & Proper & & Median & Mean \pm SD & Test st. \\
\hline \multirow{2}{*}{ Perceptual motor } & \multirow{14}{*}{ Age } & 4-year-olds & 3.60 & $3.46 \pm 0.56$ & \multirow{2}{*}{$p=0.035^{*}$} \\
\hline & & 5-year-olds & 3.80 & $3.64 \pm 0.47$ & \\
\hline \multirow{2}{*}{ Self-management } & & 4-year-olds & 2.70 & $2.83 \pm 0.67$ & \multirow{2}{*}{$p=0.000^{* *}$} \\
\hline & & 5 -year-olds & 3.80 & $3.57 \pm 0.50$ & \\
\hline \multirow{2}{*}{ Social and emotional } & & 4-year-olds & 3.50 & $3.29 \pm 0.67$ & \multirow{2}{*}{$p=0.014^{* *}$} \\
\hline & & 5-year-olds & 3.80 & $3.60 \pm 0.55$ & \\
\hline \multirow{2}{*}{ Early math } & & 4-year-olds & 3.00 & $3.12 \pm 0.63$ & \multirow{2}{*}{$p=0.00^{* *}$} \\
\hline & & 5 -year-olds & 3.70 & $3.46 \pm 0.69$ & \\
\hline \multirow{2}{*}{ Early literacy } & & 4-year-olds & 2.70 & $2.83 \pm 0.67$ & \multirow{2}{*}{$p=0.000^{* *}$} \\
\hline & & 5-year-olds & 3.60 & $3.29 \pm 0.65$ & \\
\hline \multirow{2}{*}{ Receptive language } & & 4 -year-olds & 3.90 & $3.54 \pm 0.65$ & \multirow{2}{*}{$p=0.000^{*}$} \\
\hline & & 5 -year-olds & 4.00 & $3.76 \pm 0.60$ & \\
\hline \multirow{2}{*}{ Expressive language } & & 4-year-olds & 3.50 & $3.23 \pm 0.77$ & \multirow{2}{*}{$p=0.000^{*}$} \\
\hline & & 5-year-olds & 3.80 & $3.53 \pm 0.71$ & \\
\hline \multirow{2}{*}{ Self-management } & \multirow{6}{*}{ Child's health condition } & No problems & 3.60 & $3.40 \pm 0.53$ & \multirow{2}{*}{$p=0.042^{*}$} \\
\hline & & Problems & 3.30 & $2.95 \pm 0.86$ & \\
\hline \multirow{2}{*}{ Social and emotional } & & No problems & 3.80 & $3.48 \pm 0.58$ & \multirow{2}{*}{$p=0.005^{* *}$} \\
\hline & & Problems & 2.70 & $2.87 \pm 0.87$ & \\
\hline \multirow{2}{*}{ Receptive language } & & No problems & 4.00 & $3.70 \pm 0.50$ & \multirow{2}{*}{$p=0.027^{*}$} \\
\hline & & Problems & 3.80 & $3.06 \pm 1.12$ & \\
\hline \multirow{4}{*}{ Social and emotional } & & No siblings & 3.50 & $3.37 \pm 0.63$ & \multirow{4}{*}{$p=0.002^{* *}$} \\
\hline & & 1 sibling & 3.90 & $3.57 \pm 0.55$ & \\
\hline & & 2 siblings & 3.10 & $3.08 \pm 0.80$ & \\
\hline & Number of siblings & No siblings & 3.60 & $3.31 \pm 0.70$ & \\
\hline \multirow{2}{*}{ Expressive language } & & 1 sibling & 3.80 & $3.50 \pm 0.65$ & \multirow{2}{*}{$p=0.008^{* *}$} \\
\hline & & 2 siblings & 3.60 & $3.00 \pm 0.96$ & \\
\hline
\end{tabular}

*Significant at 0.05 level. ${ }^{* *}$ Significant at 0.01 level.

TABLE 10: Pearson correlation matrix regarding learning domains.

\begin{tabular}{|c|c|c|c|c|c|c|c|c|}
\hline \multicolumn{9}{|c|}{ Correlation } \\
\hline \multicolumn{2}{|l|}{ Learning domains } & $\begin{array}{l}\text { Perceptual } \\
\text { motor }\end{array}$ & Self-management & Social-emotional & $\begin{array}{l}\text { Early } \\
\text { math }\end{array}$ & $\begin{array}{c}\text { Early } \\
\text { literacy }\end{array}$ & $\begin{array}{l}\text { Receptive } \\
\text { language }\end{array}$ & $\begin{array}{c}\text { Expressive } \\
\text { language }\end{array}$ \\
\hline \multirow{4}{*}{$\begin{array}{l}\text { Preceptual motor } \\
\text { (PM) } \\
\text { Self-management } \\
(\mathrm{SM})\end{array}$} & $r$ & 1 & $0.755^{* *}$ & $0.615^{* *}$ & $0.592^{* *}$ & $0.642^{* *}$ & $0.636^{* *}$ & $0.639^{* *}$ \\
\hline & $p$ & & 0.000 & 0.000 & 0.000 & 0.000 & 0.000 & 0.000 \\
\hline & $r$ & $0.755^{* *}$ & 1 & $0.827^{* *}$ & $0.743^{* *}$ & $0.794^{* *}$ & $0.775^{* *}$ & $0.766^{* *}$ \\
\hline & $p$ & 0.000 & & 0.000 & 0.000 & 0.000 & 0.000 & 0.000 \\
\hline \multirow{2}{*}{ Social-emotional(SE) } & $r$ & $0.615^{* *}$ & $0.827^{* *}$ & 1 & $0.657^{* *}$ & $0.711^{* *}$ & $0.738^{* *}$ & $0.757^{* *}$ \\
\hline & $p$ & 0.000 & 0.000 & & 0.000 & 0.000 & 0.000 & 0.000 \\
\hline \multirow{2}{*}{ Early math (EM) } & $r$ & $0.592^{* *}$ & $0.743^{* *}$ & $0.657^{* *}$ & 1 & $0.835^{* *}$ & $0.697^{* *}$ & $0.729^{* *}$ \\
\hline & $p$ & 0.000 & 0.000 & 0.000 & & 0.000 & 0.000 & 0.000 \\
\hline \multirow{2}{*}{ Early literacy (EL) } & $r$ & $0.642^{* *}$ & $0.794^{* *}$ & $0.711^{* *}$ & $0.835^{* *}$ & 1 & $0.744^{* *}$ & $0.783^{* *}$ \\
\hline & $p$ & 0.000 & 0.000 & 0.000 & 0.000 & & 0.000 & 0.000 \\
\hline \multirow{4}{*}{$\begin{array}{l}\text { Receptive language } \\
(\mathrm{RL}) \\
\text { Expressive language } \\
(\text { ExL) }\end{array}$} & $r$ & $0.636^{* *}$ & $0.775^{* *}$ & $0.738^{* *}$ & $0.697^{* *}$ & $0.744^{* *}$ & 1 & $0.927^{* *}$ \\
\hline & $p$ & 0.000 & 0.000 & 0.000 & 0.000 & 0.000 & & 0.000 \\
\hline & $r$ & $0.639^{* *}$ & $0.766^{* *}$ & $0.757^{* *}$ & $0.729^{* *}$ & $0.783^{* *}$ & $0.927^{* *}$ & 1 \\
\hline & $p$ & 0.000 & 0.000 & 0.000 & 0.000 & 0.000 & 0.000 & \\
\hline
\end{tabular}

$r$ : Pearson's Correlation coefficient. ${ }^{* *}$ Correlation is significant at 0.01 level.

expressive language domain with an effect rate of $19.3 \%$. It is observed that out of these effects, $21.3 \%$ of the early math domain is mostly a direct effect while the other two variables mainly have an indirect effect. Thus, early literacy learning domain is affected firstly from early math directly and subsequently from generally the self-management and expressive language domains indirectly.
As it can be seen in Table 11, there are 3 variables that affect the expressive language learning domain at a statistically significant level with an explanation rate of $86.9 \%$. These variables are listed in order of importance as expressive language domain with an effect rate of $65.1 \%$, early literacy with an effect rate of $15.1 \%$, and social and emotional domain with an effect rate of $6.7 \%$. It is observed that out of 
TABLE 11: Path analysis results.

\begin{tabular}{|c|c|c|c|c|c|}
\hline $\begin{array}{l}\text { Dependent } \\
\text { variable }\end{array}$ & Regression equation & $\begin{array}{l}\text { Independent } \\
\text { variables }\end{array}$ & $\begin{array}{c}\text { Indirect } \\
\text { effect }\end{array}$ & $\begin{array}{c}\text { Direct } \\
\text { effect }\end{array}$ & $\begin{array}{l}\text { Total } \\
\text { effect }\end{array}$ \\
\hline $\begin{array}{l}\text { Perceptual motor } \\
(\mathrm{PM})\end{array}$ & $\mathrm{PM}=1.255+0.679^{*} \mathrm{SM}$ & SM & 0 & $\begin{array}{c}0.570 \\
R \text {-square }\end{array}$ & $\begin{array}{l}0.570 \\
0.570\end{array}$ \\
\hline $\begin{array}{l}\text { Self-management } \\
(\mathrm{SM})\end{array}$ & $\mathrm{SM}=-0.004+0.309^{*} \mathrm{AM}+0.353^{*} \mathrm{SD}+0.204^{*} \mathrm{EO}+0.123 \mathrm{RL}$ & $\begin{array}{l}\text { PM } \\
\text { SE } \\
\text { EL } \\
\text { RL }\end{array}$ & $\begin{array}{l}0.133 \\
0.170 \\
0.133 \\
0.085\end{array}$ & $\begin{array}{c}0.077 \\
0.148 \\
0.059 \\
0.018 \\
R \text {-square }\end{array}$ & $\begin{array}{l}0.210 \\
0.318 \\
0.192 \\
0.103 \\
0,823\end{array}$ \\
\hline $\begin{array}{l}\text { Social and } \\
\text { emotional (SE) }\end{array}$ & $\mathrm{SE}=0.371+0.654^{*} \mathrm{SM}+0.254^{*} \mathrm{ExL}$ & $\begin{array}{l}\mathrm{SM} \\
\mathrm{ExL}\end{array}$ & $\begin{array}{l}0.137 \\
0.137\end{array}$ & $\begin{array}{c}0.358 \\
0.089 \\
R \text {-square }\end{array}$ & $\begin{array}{l}0.495 \\
0.226 \\
0.721 \\
\end{array}$ \\
\hline Early math (EM) & $\mathrm{EM}=0.854+0.799^{*} \mathrm{EL}$ & EL & 0 & $\begin{array}{c}0.698 \\
R \text {-square }\end{array}$ & $\begin{array}{l}0.698 \\
0.698\end{array}$ \\
\hline Early literacy (EL) & $\mathrm{EL}=-0.373+0.313^{*} \mathrm{SM}+0.228^{*} \mathrm{ExL}$ & $\begin{array}{l}\text { SM } \\
\text { EM } \\
\text { ExL }\end{array}$ & $\begin{array}{l}0.140 \\
0.173 \\
0.132\end{array}$ & $\begin{array}{c}0.069 \\
0.213 \\
0.061 \\
R \text {-square }\end{array}$ & $\begin{array}{l}0.209 \\
0.385 \\
0.193 \\
0.787 \\
\end{array}$ \\
\hline $\begin{array}{l}\text { Receptive language } \\
(\mathrm{RL})\end{array}$ & $\mathrm{RL}=0.795+0.168^{*} \mathrm{SM}+0.678^{*} \mathrm{ExL}$ & $\begin{array}{l}\text { SM } \\
\text { ExL }\end{array}$ & $\begin{array}{l}0.096 \\
0.096\end{array}$ & $\begin{array}{c}0.024 \\
0.651 \\
R \text {-square }\end{array}$ & $\begin{array}{l}0.121 \\
0.748 \\
0.869 \\
\end{array}$ \\
\hline $\begin{array}{l}\text { Expressive } \\
\text { language (ExL) }\end{array}$ & $\begin{array}{c}\mathrm{ExL}=-0.421+0.073^{*} \mathrm{PM}+0.353^{*} \mathrm{SE}+0.156^{*} \mathrm{EL}+0.506 \\
123 \mathrm{RL}\end{array}$ & $\begin{array}{l}\text { SE } \\
\text { EL } \\
\text { RL }\end{array}$ & $\begin{array}{l}0.059 \\
0.114 \\
0.148\end{array}$ & $\begin{array}{c}0.008 \\
0.037 \\
0.503 \\
R \text {-square }\end{array}$ & $\begin{array}{l}0.067 \\
0.151 \\
0.651 \\
0.869\end{array}$ \\
\hline
\end{tabular}

these effects, $50.3 \%$ of the receptive language domain is mostly a direct effect while the other two variables mainly have an indirect effect. Therefore, expressive language is dependent firstly on receptive language domain directly and subsequently to early literacy and social and emotional learning domains indirectly.

According to Table 11, there are 4 variables that affect the self-management domain at a statistically significant level with an explanation rate of $82.3 \%$. These variables are listed in order of importance as social and emotional domain with an effect rate of $31.8 \%$, perceptual motor domain with an effect rate of $21.0 \%$, and early literacy domain with an effect rate of $10.3 \%$. These 4 effects that are statistically significant are all mainly direct effects, and it can be said that the effects on self-management learning domain are generally indirect effects. Thus, it can be said that social and emotional, perceptual and motor, early literacy, and expressive language domains need to be developed together for a child with weak self-management domain.

General evaluation of the path analysis results shows that self-management domain generally affects the perceptual motor and the social and emotional domains at a great rate, which is mostly directly, that early literacy domain effects the early math domain directly at a great rate, and that expressive language domain and expressive language domains effect each other mostly directly at a great rate. Thus, the significant variables that are important in terms of development of learning domains can be listed from higher to lower effect as self-management, expressive language, early literacy, and receptive language. In conclusion, it can be considered that efforts to improve these 4 learning domains in general in the 4-5-year-old children can lead to development of all learning domains.

\section{Results and Discussion}

Turkish adaptation of the ELORS scale and reliability-validity studies has been conducted, and the outputs have been evaluated with its use in a Turkey sample. ELORS is a valuable tool because of its sound theoretical foundation, and the valid and reliable evidence that it provides in psychometric terms. ELORS aims at early recognition of the difficulties faced by small children and ensuring early response and early support. Because the earlier the difficulties are recognized, the sooner the support can be provided, which leads to overcoming the problems and distancing the related potential problems more possible [19].

Following adaptation to Turkish, a pilot study was carried out to examine the validity and reliability of the scale. It was found that the face and social validity of the scale is high and that the results are compatible with the applicability and practicality results obtained from the original study. Thus, it can be said that the scale is a useful and practical scale based on the results of its application in Turkey. In the pilot application of the ELORS form adapted to Turkish, consisting of 60 observations, Chronbach Alpha values were examined to investigate the content validity of each of the seven learning domains. As a result of the examination, it was observed that 4 items had a slightly reducing effect on reliability and these items were reviewed and corrected. Following this revision, it was determined that none of the items of the scale in the research application, 
consisting of 166 observations, had any adverse effect on reliability in any domain. Thus, it was concluded that content validity of each of the seven learning domains could be established without removing any item from the ELORS when a sample size that will be representative of the mass is reached.

Conformity of the construct validity of the scale was examined. The variance explanation rates of all domains have been found as different values in the $73 \%$ and $89 \%$ range. Thus, it has been decided that each domain could explain one subdimension at a great rate when a sample of efficient size is taken to represent the population. In conclusion, construct validity of Turkish form of ELORS was found to be at a good level.

In conclusion, it can be said that the early learning observation and rating scale-teacher's form is a suitable tool to evaluation and monitoring by observation early learning and development processes of children in Turkey. This rating tool will provide for identification of children in needs of special service in the classroom by the educator and thus early intervention. Study result indicates that the support programs to be prepared must be holistic and individual with the direct and indirect relationships in learning domains determined with detailed studies on found insufficiencies. In this context, it is believed that it will contribute to the measuring tools that can evaluate the learning and development processes of small children in detail in our country. ELORS is an instrument that is easy to use, practical, useful, and cost-effective with fast application, and more importantly, it is capable of presenting correct information to the educator by evaluating the difficulties encountered by the children functionally.

Moreover, as the second objective of our study, ELORS, which was adapted to Turkish, was used in the Turkey sample and results were evaluated. Based on information obtained, it was found that development process of the child continued with age in each of the 7 learning domains; health problem of the child affected the self-management, socialemotional, and receptive language domains; and those with two siblings had higher level of social-emotional and expressive language scores compared to single children or those who are 3 siblings. Path analyses were made to determine the causality among the seven learning domains through the use of ELORS-teacher's form adapted to Turkish. Indirect effect, direct effect, and total effects were obtained in path analysis. Based on these outputs, it is seen that self-management domain generally affected the sensorimotor and social and emotional domain directly at a high rate, and that receptive language and expressive language domains affected each other directly in general at high rates. Thus, variables that are important in development of the learning domains of learning are listed as self-management, expressive language, early literacy, and receptive language domains based on superiority of affecting. Briefly, it can be concluded that all learning domains can be developed by working to improve these 4 learning domains in general in children in the 4-5-year-old group.

\section{Data Availability}

The data are available from the author(s) upon request.

\section{Conflicts of Interest}

The author(s) declare no potential conflicts of interest with respect to the research, authorship, and/or publication of this article.

\section{Acknowledgments}

The authors would like to thank Mary Ruth Coleman, Tracy West, and Margaret Gills for developing the scale-teachers form and allowing us to adapt this form to Turkish. The authors express their gratitude to those who contributed to the study.

\section{References}

[1] M. Rutter, "The interplay of nature, nurture, and developmental influences: the challenge ahead for mental health," Archives of General Psychiatry, vol. 59, no. 11, pp. 996-1000, 2002.

[2] H. Bee and D. Boyd, The Developing Child, Allyn \& Bacon Publisher, Boston, MA, USA, 12 edition, 2009, ISBN: 9780205685936.

[3] E. L. Berk, Infants and Children: Parental through Middle Childhood, Pearson Education Inc., New York, NY, USA, 7th edition, 2011, ISBN: 978-0205011087.

[4] R. Wegerif, "Teaching thinking: metaphors and taxonomies," Dialogic Education and Technology, Springer, Boston, MA, USA, 2007.

[5] K. E. Glevery, “Thinking skills in England's National curriculum," Improving Schools, vol. 11, no. 2, pp. 115-125, 2008.

[6] S. Wolf and N. M. Suntheimer, "A dimensional risk approach to assessing early adversity in national sample," Journal of Applied Developmental Psychology, vol. 62, pp. 270-281, 2019.

[7] K. Tepeli, "Development in early childhood," "Development in early childhood," in Motor (Motion) Development, E. Deniz, Ed., Maya Academy, Ankara, Turkey, 2010.

[8] Ç. Aytekin, "Child development from prenatal to adolescence,"“Child development from prenatal to adolescence," in Physical Growth and Motor Development, N. Metin Baysal, Ed., Pegem Academy, Ankara, Turkey, 2017, ISBN: 978-605318-592-5.

[9] E. Singer, Child Care and Psychology of Development, Routledge, London, UK, 1st edition, 2017, ISBN: 978-13516782247.

[10] R. Kale, Physical Education and Game Teaching in Primary Education, Pegem A Publishing, Ankara, Turkey, 2007.

[11] M. J. Gander and H. W. Gardiner, Child and Adolescent Development, A. Dönmez, N. Çelen, and B. Onur, Eds., , İmge Bookstore, Ankara, Turkey, 4th edition, 2001.

[12] Y. Özbay, Developmental and Learning Psychology, Academy Bookstore, Trabzon, Turkey, 4th edition, 2003.

[13] K. P. Smith, H. Cowie, and M. Blades, Understanding Children's Development, John Wiley \& Sons Ltd., London, UK, 6th edition, 2015, ISBN: 978-1118772980.

[14] R. Charlesworth, "Prekindergarten mathematics: connecting with National standards," Early Childhood Education Journal, vol. 32, no. 4, pp. 229-236, 2005. 
[15] N. Dönmez, Ü. Abidoğlu, Ç. Dincer, N. Erdemir, and Ş. Gümüscü, Language Development Activities (Dil Gelişimi Etkinlikleri), Ya-Pa Publishing, İstanbul, Turkey, 3rd edition, 2000.

[16] Z. Wang, B. Soden, K. Deater-Deckand, and S. L. Lukowski, "Developing in reading and math in children from different SES back grounds: the moderating role of child temperament," Developmental Science, vol. 20, pp. 1-8, Article ID e12380, 2017.

[17] P. E. Shah, H. M. Weeks, B. Richards, and N. Kcirati, "Early childhood curiosity and kindergarten reading and math academic achievement," Pediatric Research, vol. 84, no. 3, pp. 380-386, 2018.

[18] M. van Witteloostujin, I. Lammerthink, P. Boersma, F. Wijnen, and J. Rispens, "Assessing visual statistical learning in early-school-aged children: the usefulness of an online reaction time measure," Frontiers in Psychology, vol. 10, p. 2051, 2019.

[19] M. R. Coleman, T. West, and M. Gillis, The Early Learning Observation and Rating Scale: Teacher Individual Child Form, National Center for Learning Disabilities, New York, NY, USA, 2010.

[20] S. Baykan, Z. F. Temel, Ö. Ersoy, and N. Avc1, Development Process of Gazi Early Childhood Assessment Tool (GECAT), Early Childhood Development and Education Symposium "Looking to the Future" Proceeding Book, Kök Publishing, Ankara, Turkey, 2002.

[21] M. Bertan, D. Haznedaroğlu, P. Koln, K. Yurdakök, and B. Güçiz, "Studies on early childhood development in Turkey (2000-2007)," Journal of Child Health and Diseases, vol. 52, no. 1, pp. 1-8, 2007.

[22] A. Rhoad-Drogalis, B. E. Sawyer, L. M. Justice, and A. A. O'Connel, "Assessing learning behaviors in early childhood special education classrooms," Early Education and Development, vol. 29, no. 4, pp. 450-466, 2018.

[23] N. Rao, J. Sun, B. Richards et al., "Assessing diversity in early childhood development in the east Asia-Pacific," Child Indicators Research, vol. 12, pp. 235-254, 2019.

[24] J. Piaget and M. Cook, The Origins of Intelligence in Children, W. W Norton \& Co., New York, NY, USA, 1952.

[25] S. Gouteuxa, J. Vauclairb, and C. Thinus, "Reorientation in small-scale environment by 3-4 and 5 years old children," Cognitive Development, vol. 16, no. 3, pp. 853-869, 2001.

[26] H. M. Develi and K. Orbay, "On the development of number concept in pre- procedure children," 5th National Congress of Science and Mathematics Education, Middle East Technical University, Ankara, Turkey, 2002.

[27] Y. Aydoğan and N. Koçak, "Investigation of factor affecting the pre-school children's language development (Konya Province Case)," The Journal of National Education, vol. 159, 2003, http://www.meb.gov.tr.

[28] L. Pagani, "The impact of junior kindergarten on behaviour in elementary school children," International Journal of Behavioral Development, vol. 27, no. 5, pp. 423-427, 2003.

[29] Y. Güven, "Intuitional mathematics ability preschool children," Marmara University Journal of Institute of Social Sciences, vol. 7, no. 28, pp. 389-395, 2007.

[30] P. M. Cole, S. E. Martin, and T. A. Dennis, "Emotions regulation as a scientific construct: methodological challenges and directions for child development research," Child Development, vol. 72, no. 2, pp. 317-333, 2004.

[31] S. M. Carlson, D. J. Mandell, and L. Williams, "Executive function and theory of mind: stability and prediction from ages 2 to 3," Developmental Psychology, vol. 40, no. 6, pp. 1105-1122, 2004.

[32] V. A. Marchman and A. Fernald, "Speed of word recognition and vocabulary knowledge in infancy predict cognitive and language outcomes in later childhood," Developmental Science, vol. 11, no. 3, pp. 339-432, 2008.

[33] S. Saraç, S. Karakelle, and D. Whitebread, "Children independent learning development checklist 3-5 (child 3-5): validity and reliability study for the Turks form," Elementary Education Online, vol. 18, no. 3, pp. 1093-1106, 2019, http:// ilkogretim-online.org.tr.

[34] A. Sincovich, T. T. Gregory, C. Zanon, and D. D. Santos, "Measuring early child development in low and middle income countries: investigating the validity of the early human capability index," BMC Pediatrics, vol. 19, no. 471, pp. 2-14, 2019.

[35] A. Bagdi and J. Vacca, "Supporting early childhood socialemotional well-being: the building blocks for early learning and school success," Early Childhood Education, vol. 33, no. 3, pp. 145-150, 2005.

[36] N. Howe, R. J. Persram, and C. Bergeron, "Siblings relationships in adolescence," The Encyclopedia of Child and Adolescent Development, John Wiley \& Sons Inc., New York, NY, USA, 2019.

[37] T. Saini, S. Sharma, and T. Kaur, "Social emotional learning and temperament among children with and without siblings," Indian Journal of Positive Psychology, vol. 10, no. 3, pp. 162-168, 2019.

[38] L. Kaminsky and D. Dewey, "Siblings relationships of children with autism," Journal of Autism and Developmental Disorders, vol. 31, no. 4, pp. 399-410, 2001.

[39] E. Arslan, N. Durmuşoğlu-Saltalı, and H. Yılmaz, "Social skills and emotional and behavioral traits of preschool children," Social Behaviour and Personality, vol. 39, no. 9, pp. 1281-1288, 2011.

[40] H. G. Ogelman and H. Sarıkaya Erten, "Relationships between variables of sibling and social skills, peer relations and school adjustment levels of 5-6 years old children," Akademik Bakış International and Refereed Journal of Social, vol. 41, pp. 1-11, 2014.

[41] M. E. Olobatuyi, A User's Guide to Path Analysis, Include: The Use of Path Analysis, University Press of America, New York, NY, USA, 2006. 